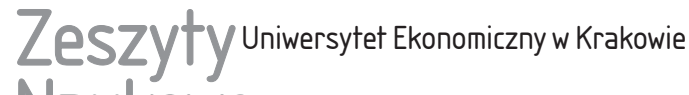 Naukowe
}

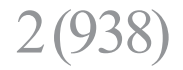

ISSN 1898-6447

Zesz. Nauk. UEK, 2015; 2 (938): 71-85 DOI: 10.15678/ZNUEK.2015.0938.0206

Irena Pyka

Katedra Bankowości i Rynków Finansowych

Uniwersytet Ekonomiczny w Katowicach

\section{Dylematy banków centralnych wobec polityki luzowania ilościowego}

\section{Streszczenie}

Opracowanie koncentruje się na analizie charakteru i form zastosowanej przez banki centralne w okresie globalnego kryzysu finansowego polityki luzowania ilościowego (quantitative easing). Bezpośrednim jego celem jest ocena skutków tej polityki. Ich analizę przeprowadzono w płaszczyźnie teoretycznej i w wymiarze realnym, wskazując na ich różnorodność warunkującą realizację przez banki centralne tzw. strategii wyjścia.

Słowa kluczowe: ekspansja monetarna, niestandardowe instrumenty polityki monetarnej, polityka luzowania ilościowego, nadzwyczajna polityka monetarna, strategie wyjścia, bilans banku centralnego, kreacja pieniądza kredytowego.

\section{Wprowadzenie}

Luzowanie ilościowe (quantitative easing - QE) to instrument nadzwyczajnej polityki monetarnej banków centralnych wykorzystany w celu przywrócenia stabilności finansowej doświadczonej globalnym kryzysem finansowym gospodarki światowej. Największe banki centralne politykę luzowania ilościowego zastosowały w warunkach niskiej skuteczności niestandardowych instrumentów polityki monetarnej skierowanych na utrzymanie i pobudzenie wzrostu gospodarczego. Endogeniczny wzrost ilości pieniądza w obiegu gospodarczym wspoma- 
gany polityką niskich stóp procentowych okazał się kontrowersyjnym, aczkolwiek skutecznym narzędziem aktywizacji współczesnej gospodarki światowej.

Celem opracowania jest identyfikacja zastosowanych przez banki centralne form polityki luzowania ilościowego skierowana na wskazanie ich różnorodnych skutków ekonomiczno-finansowych w gospodarce. Analiza tych skutków prowadzona w płaszczyźnie teoretycznej i w wymiarze realnym pozwala stwierdzić, że banki centralne z uwagi na ich silne wzajemne powiązania zdecydowały się na „małe kroki” w realizacji exit strategy (strategia wyjścia), obawiając się szokowej reakcji rynków finansowych i gospodarki. Przyjętą zasadę wyjścia wspiera brak w krótkim okresie efektów inflacyjnych polityki luzowania ilościowego, a także pozytywny jej wpływ na ożywienie gospodarcze państw wysoko rozwiniętych. Banki centralne prowadzą więc nadal politykę luzowania ilościowego, ograniczając stopniowo wolumen skupowanych aktywów finansowych i wspomagając go utrzymaniem w mocy większości swych instrumentów niestandardowych.

\section{Polityka luzowania ilościowego - nowa czy klasyczna ekspansja monetarna?}

Polityka luzowania ilościowego została wprowadzona przez banki centralne w drugim etapie przeciwdziałania skutkom globalnego kryzysu finansowego. Niska skuteczność niestandardowych instrumentów polityki monetarnej spowodowała, że banki centralne zdecydowały się na zwiększanie podaży pieniądza w gospodarce poprzez kupno aktywów finansowych od banków lub bezpośrednio z rynku. Często argument ten przesądza o tym, że luzowanie ilościowe uznaje się za instrument nadzwyczajny antykryzysowej polityki monetarnej banków centralnych. Zasadniczo jednak jest ono formą ekspansywnej polityki monetarnej skierowanej, podobnie jak niestandardowe instrumenty polityki monetarnej, na stymulowanie koniunktury gospodarczej.

Banki centralne jeszcze przed globalnym kryzysem finansowym dokonywały nieraz skupu papierów wartościowych bezpośrednio z rynku finansowego. Głównie nabywały one kwalifikowane aktywa finansowe w operacjach otwartego rynku. Papiery wartościowe stanowią też przedmiot obrotu w procesie tzw. refinansowania banków komercyjnych przez bank centralny. Banki centralne nierzadko także skupują skarbowe papiery wartościowe, finansując dług publiczny. Negatywne doświadczenia z nim związane spowodowały, że większość z nich uniezależniła się od takiego finansowania, upatrując w nim autonomicznego czynnika wzrostu bazy monetarnej i osłabienia kontroli podaży pieniądza kredytowego.

Polityka luzowania ilościowego jako szczególna forma ekspansywnej polityki monetarnej skierowanej na pobudzenie wzrostu gospodarczego pojawiła się 
w Japonii na długo przed globalnym kryzysem finansowym. Kraj ten, zmagając się od początku lat 90. XX w. z nasilającą się deflacją, permanentnie „psuje” mocnego jena. Bank Japonii drukuje zatem bez ograniczeń japońską walutę, ostatnio masowo wspomagając odbudowę regionów zniszczonych przez trzęsienie ziemi i tsunami. Nowy premier Japonii też podjął działania, których celem byłoby zakończenie niemalże 20-letniego okresu przedłużającej się deflacji. Jego program oparty jest na tzw. polityce trzech strzałek (abekonomia), czyli polityce pieniężnej, fiskalnej oraz polityce strukturalnych reform. Planuje on zwiększenie wydatków publicznych w kraju, w którym - według MFW - dług publiczny w stosunku do wielkości gospodarki wynosi ok. 236\% (jest to najwyższy na świecie dług publiczny). Prowadzona aktualnie przez Bank Japonii luźna polityka pieniężna polega na comiesięcznym skupie z rynku obligacji skarbowych o wartości $80 \mathrm{mld}$ dolarów i zwiększaniu tą drogą ilości pieniądza w obiegu. Osiągnięcie wzrostu inflacji mają zapewnić w Japonii zakupy także innych nieskarbowych aktywów finansowych przez Bank Japonii. Od stycznia 2014 r. do odwołania będzie on kupował każdego miesiąca takie aktywa o wartości 13 bln jenów, czyli ok. 145 mld dolarów, przy czym skala zakupów jest nielimitowana.

Przykład Japonii wskazuje, że quantitative easing to szczególny instrument ekspansji monetarnej. Można go traktować jako jej instrument nadzwyczajny, wspomagany nadzwyczajną polityką budżetową państwa i stosowany w długich okresach pobudzania wzrostu gospodarki. Skutki, które powoduje w gospodarce, dodają mu cech szczególnej trwałości. Największe banki centralne nie zdołały się bowiem wycofać z polityki luzowania ilościowego do 2014 r., pomimo przyjętych przez nie tzw. strategii wyjścia bezpośrednio po globalnym kryzysie finansowym.

Quantitative easing, jako forma ekspansywnej polityki monetarnej, różni się także zasadniczo od jej instrumentów niestandardowych. Powstawanie tych instrumentów opierało się bowiem wprost na klasycznych regulatorach polityki monetarnej. Banki centralne do utrzymywania krótkoterminowej stopy procentowej rynku międzybankowego na wyznaczonym przez siebie poziomie, kontrolując tą drogą podaż pieniądza bankowego i poziom cen w gospodarce, w okresie bezpośrednio poprzedzającym globalny kryzys finansowy wykorzystywały do tych celów politykę refinansową, rezerwę obowiązkową czy operacje otwartego rynku [Gray i Hoggarth 1996, s. 15]. Ich zmodyfikowane technicznie formy, określane mianem niestandardowych instrumentamów polityki monetarnej, banki centralne zastosowały w pierwszej fazie eskalacji globalnego kryzysu finansowego. W swej niestandardowej polityce monetarnej skoncentrowały się one na [Pyka 2013, s. 507]:

- likwidacji barier w dostarczaniu ilości środków płynnych na rynku międzybankowym,

- obniżkach podstawowych stóp procentowych, 
- wykorzystaniu linii swapowych w transakcjach z innymi bankami centralnymi,

- poszerzeniu zakresu instrumentów finansowych stosowanych do zabezpieczenia transakcji banków komercyjnych z bankami centralnymi.

Tą drogą banki centralne skorzystały z dobrych dotychczas doświadczeń, za pomocą niestandardowych instrumentów reagowały bowiem już wcześniej na liczne naruszenia równowagi monetarnej rynków finansowych w gospodarce światowej drugiej połowy XX w. Nie naruszały przy tym ram swej operacyjnej polityki pieniężnej. Niestandardowe instrumenty polityki pieniężnej, w przeciwieństwie do quantitative easing, służyły bowiem zawsze regulowaniu krótkoterminowej płynności sektora bankowego. Różne są również kanały oddziaływania tych instrumentów na gospodarkę.

Obniżenie stopy procentowej banki centralne stosują, kierując się wzrostem akcji kredytowej w celu pobudzenia wzrostu inwestycji gospodarczych. Siła tej zależności zależy jednak od elastyczności inwestycji na zmiany stopy procentowej. Dlatego też ekspansja monetarna może okazać się w różnym stopniu efektywna, a stymulowany wzrostem inwestycji popyt globalny może prowadzić do zróżnicowanej dynamiki przyrostu dochodu narodowego. Również rola banków centralnych w tym procesie, zważywszy na ramy ustrojowe i operacyjne polityki monetarnej, jest nieduża. Wpływają one bowiem bezpośrednio wyłącznie na poziom krótkoterminowych stóp procentowych. Tymczasem koszt inwestycji rynku kapitałowego zależy od długoterminowych stóp procentowych. Obniżka stóp procentowych, jako instrument polityki monetarnej, jest zatem w różnym stopniu skuteczna i zdeterminowana wieloma czynnikami pobudzania koniunktury gospodarczej.

Obniżanie stopy rezerwy obowiązkowej zastosowane przez banki centralne to instrument oddziałujący wyłącznie na ilość pieniądza bankowego. Współczesny system rezerwy obowiązkowej, zróżnicowany pod względem technik jej obliczania, naliczania i utrzymywania, służy głównie łagodzeniu wpływu bieżących zmian płynności systemu bankowego na stopy procentowe rynku międzybankowego. Dlatego też ekspansja podażowa powodowana obniżeniem stopy rezerwy obowiązkowej jest krótkoterminowa i w niewielkim stopniu wpływa na koszt pozyskania środków finansowania bankowego. Instrument ten ma jedynie charakter wspomagający kształtowanie podaży pieniądza kredytowego w gospodarce.

Powyższe przyczyny zdecydowały o tym, że największe banki centralne w okresie globalnego kryzysu finansowego zastosowały mechanizm rezerwy obowiązkowej łącznie z polityką obniżki stóp procentowych. Wzmocniły go także bezprecedensową decyzją o wspólnym obniżeniu stóp procentowych w październiku 2008 r. i wspólną inicjatywą linii swapowych. Fed podpisał umowy swapowe z 14 bankami centralnymi [Bernanke 2009], dystrybuując w ten sposób płynność 
dolarową nie tylko przez amerykański bank centralny, ale także na inne państwa gospodarki światowej, w tym także w Europie. W ten sposób zmniejszano presję na rynku amerykańskim i ograniczano ewentualny wzrost stóp procentowych.

Linie swapowe wygasły jednak w lutym 2010 r. Okazało się też, że obniżanie stóp procentowych, rezerwy obowiązkowej i wsparcie płynnościowe ze strony banków centralnych nie wystarcza do przywracania stabilności finansowej i koniunktury gospodarki globalnej. Nieskuteczność podejmowanych przez banki centralne działań wyzwoliła obawę o wystąpienie zjawiska credit crunch, oznaczającego wystąpienie kryzysu na rynku kredytowym w postaci nagłego wzrostu kosztów pożyczek albo ich niedoborów. Dlatego też wybrane banki centralne podjęły dalsze działania mające na celu podtrzymanie akcji kredytowej. Władze monetarne państw gospodarki światowej (np. amerykańskie) rozpoczęły skup wielu papierów emitowanych przez podmioty prywatne [Banki centralne... 2010, s. 116].

\section{Współczesna polityka luzowania ilościowego. Rodzaje i skutki}

Przyjmuje się obecnie, że luzowanie ilościowe jako instrument nadzwyczajnej polityki monetarnej banków centralnych polega na kupnie aktywów finansowych, najczęściej od banków (np. rządowych papierów wartościowych), ale dotyczyć może także innych papierów wartościowych skupowanych bezpośrednio w transakcjach na otwartym rynku finansowym. Bezpośrednim celem polityki luzowania ilościowego jest dostarczanie podmiotom finansowym, głównie bankom, środków pieniężnych niezbędnych do zwiększenia ich aktywności kredytowej. Polityka luzowania ilościowego niesie zatem ze sobą ryzyko wzrostu cen. Oznacza bowiem niekontrolowany wzrost podaży pieniądza, czyli nieskorelowany z przyrostem potencjału gospodarczego lub (i) ze wzrostem na rynku ilości dóbr i usług. Jest w związku z tym obarczana odpowiedzialnością za generowanie inflacji. Banki centralne z nasiloną inflacją, szczególnie ostrą w latach 70. poprzedniego stulecia, nauczyły się skutecznie walczyć. Do okresu globalnego kryzysu finansowego respektowały one porozumienia z Jackson Hole oparte na nieingerencji w kształtowanie cen aktywów finansowych [Issing 2009, s. 46]. Zasady tej nie przekraczały, co oznacza, że poprzez wykup różnych papierów wartościowych banki centralne nie dokonywały monetyzacji długu prywatnego. Luzowanie ilościowe ograniczały zasadniczo do transakcji w sektorze bankowym, regulując swoją krótko-, ale także długoterminową płynność finansową.

Polityka luzowania ilościowego w okresie globalnego kryzysu finansowego charakteryzowała się jednak tym, że banki centralne przejmowały do portfela swych aktywów finansowych różne papiery wartościowe i instrumenty dłużne. Powiększały one nadmiernie poziom ryzyka inwestycyjnego w bilansach banków 
centralnych, przyczyniając się do podziału transakcji w ramach polityki luzowania ilościowego na dwie grupy: quantitative easing i credit easing.

Quantitative easing wiąże się z regulowaniem płynności sektora bankowego poprzez wykup zgromadzonych w nim papierów wartościowych. Celem tych transakcji jest obniżanie rynkowych stóp procentowych. Credit easing ma na celu ułatwienie dostępu do finansowania podmiotom sfery realnej. Efektem credit easing powinno być zmniejszenie premii za ryzyko, jaką płacą podmioty sfery realnej. Credit easing jest połączeniem polityki kredytowej z polityką quasi-zarządzania długiem publicznym [Tymoczko 2010, s. 1].

$\mathrm{W}$ strefie euro quantitative easing zastosowano $\mathrm{w}$ trzech postaciach [Smaghi 2009, s. 3]:

- direct quantitative easing - do tej formy zalicza się program Securities Markets Programme (SMP),

- direct credit easing - realizowany w programach Covered Bond Purchase Programme (CBPP) i SMP,

- indirect quantitative easing - w tym Longer Term Refinancing Operations (LTRO), operacje otwartego rynku na dłuższe terminy.

$\mathrm{W}$ przypadku direct guantitative easing Europejski Bank Centralny (EBC) tradycyjnie koncentrował się na zakupie długoterminowych obligacji rządowych od banków. Celem takiej transakcji było oddziaływanie na właściwą wycenę rynkową prywatnych papierów wartościowych. Zakup obligacji rządowych powodował równoległy do nich spadek rentowności prywatnych papierów wartościowych [Smaghi 2009].

Direct credit easing obejmował zakup przez EBC papierów komercyjnych w postaci obligacji korporacyjnych i papierów wartościowych zabezpieczonych aktywami (sekurytyzacja aktywów). Bezwarunkowy zakup tych papierów wartościowych równoznaczny był z ich utrzymywaniem w bilansie EBC do terminu wykupu. EBC tym samym stawał się kredytodawcą, podobnie jak każdy bank komercyjny. Poprzez ten instrument EBC mógł zmieniać przebieg krzywej dochodowości - terminową strukturę stóp procentowych - na okres zobowiązania się do wykonywania tych transakcji [Smaghi 2009].

Indirect quantitative easing z kolei ułatwiał dostęp instytucjom kredytowym do pieniądza banku centralnego, pożyczając go na dłuższe terminy i na warunkach specjalnie określonych bez konieczności zakupu papierów wartościowych. Dokonywał się on endogennie na podstawie preferencji płynnościowych banków komercyjnych i zasadniczo wtedy, gdy rynek międzybankowy był w głębokiej nierównowadze.

Podobne operacje skupu papierów wartościowych, chociaż o szerszym zakresie i na większą skalę, przeprowadzał Fed. W grudniu 2007 r. przygotował program Term Auction Facility (TAF), w ramach którego instytucje depozytowe mogły 
pozyskać finansowanie na okres do 3 miesięcy. Kolejnym programem Fed był Term Securities Lending Facility (TSLF) stworzony w marcu 2008 r., oparty na papierach skarbowych, ale także na dłużnych papierach korporacyjnych, papierach komunalnych, MBS-ach i ABS-ach. TSLF był stopniowo wygaszany i skonczył się w lutym 2010 r. W 2008 r. Fed przygotował programy Primary Dealer Credit Facility (PDCF) i Commercial Paper Funding Facility (CPFF) - oparte na zakupie CP oraz ABCP. Realizował też w kolejności program Money Market Investor Funding Facility (MMIFF) oraz w ramach programu Asset-Backed Commercial Paper Money Market Mutual Fund Lending Facility (AMLF).

Polityka luzowania ilościowego prowadzona przez Fed okazała się wieloetapowa. Pierwsza runda skupu papierów wartościowych - tzw. QE1, zakończona w marcu 2010 r., zamknęła się wprowadzeniem do gospodarki amerykańskiej 2,1 bln dolarów. Drugi etap - QE2, który rozpoczął się w listopadzie 2010 r., zakończył się na koniec czerwca 2011 r. Skupiono z rynku finansowego papiery skarbowe i MBS-y na kwotę 600 mld dolarów [Wróbel 2012]. Kolejna runda luzowania ilościowego przez Fed (QE3) rozpoczęła się we wrześniu 2012 r. Rezerwa Federalna ogłosiła nowy program skupu obligacji zabezpieczonych hipotekami MBS wartych 40 mld dolarów miesięcznie. Program QE3 nie został ograniczony czasowo.

Polityka luzowania ilościowego spowodowała poważne zmiany w bilansach banków centralnych. Programy quantitative easing przyczyniły się do nieoczekiwanego przyrostu wielkości ich sumy bilansowej. Po stronie aktywów wzrost ten był powodowany przyrostem ilości papierów wartościowych nabywanych w nadzwyczajnych programach ich zakupu przez banki centralne. Natomiast po stronie pasywów wzrastała na poziomie odpowiadającym tym programom wielkość pieniądza rezerwowego banków centralnych [Murray 2009, s. 1].

W okresie przed globalnym kryzysem finansowym banki centralne prowadziły bardzo ostrożną tzw. politykę bilansu centralnego. Polityka ta była identyfikowana z interwencjami walutowymi, quasi-polityką zarządzania długiem publicznym, polityką kredytową czy polityką rezerw bankowych [Borio i Disyatat 2009, s. 6 i nast.] i nie naruszała ram operacyjnych polityki monetarnej banków centralnych. Banki centralne w ramach quasi-polityki zarządzania długiem publicznym skupowały skarbowe papiery wartościowe, przejmując je do portfela swoich aktywów z równoczesnym finansowaniem przez nie potrzeb budżetowych. Efekt przeprowadzanej transakcji nie różni się w nich zatem od efektu związanego z wykupem prywatnych papierów wartościowych. Można mu jedynie przypisać funkcję publiczną uzasadniającą wzrost podaży pieniądza w gospodarce. W polityce luzowania ilościowego skup papierów wartościowych przeprowadzany w operacjach otwartego rynku przekroczył ramy jakiejkolwiek kontroli podaży pieniądza rezer- 
wowego banków centralnych. Działania te trudno określić jako niestandardowe. Niewątpliwie ich charakter jest nadzwyczajny.

\section{Polityka luzowania ilościowego a exit strategy}

Termin exit strategy pojawił się w polityce monetarnej banków centralnych pod koniec 2010 r. Wtedy to większość z nich, obserwując poprawę koniunktury w gospodarce światowej, przyjęła programy „bezbolesnego wycofania się” z dotychczas prowadzonej nadzwyczajnej polityki pieniężnej. Strategie wyjścia zostały zaimplementowane przez banki centralne z teorii inwestycyjnej, w której pojęcie to oznacza zamiar wyjścia z inwestycji dokonanych w przeszłości. Celem działania jest natomiast ograniczenie strat możliwych w związku ze zmianą warunków inwestycyjnych.

Banki centralne, akceptując exit strategies, uzależniły ich realizację właśnie od zmiany warunków. Prezes Fed B. Bernanke, występując przed amerykańskim Kongresem, powiązał wychodzenie z polityki luzowania ilościowego z sytuacją makroekonomiczną, w tym szczególnie na rynku pracy. Bank Anglii, przedstawiając strategię wyjścia w brytyjskim parlamencie, założył, że wycofanie się z polityki luzowania ilościowego zostanie poprzedzone wzrostem stóp procentowych. Z kolei Rada Prezesów EBC zakończenie polityki wyjścia w znacznym stopniu warunkuje realizacją celu inflacyjnego. Wysokie zagrożenie deflacyjne w strefie euro, coraz silniejsze euro i wzrost oczekiwań co do przyspieszenia wzrostu gospodarczego - to czynniki sprzyjające odroczeniu strategii wyjścia w strefie euro na dalszą perspektywę. Dlatego też Rada Prezesów EBC nie wyklucza dalszego luzowania polityki pieniężnej, gdy zajdzie taka potrzeba.

Z perspektywy globalnej kontynuacja polityki luzowania ilościowego nie ma zatem przeszkód. Rys. 1 prezentuje dane na temat wzrostu gospodarczego w wybranych krajach rozwiniętych. Jak widać, banki centralne ważnych w skali międzynarodowej państw wysoko rozwiniętych podążają od 2009 r. ścieżką wzrostu gospodarczego. Jedynie poważne problemy z przyrostem PKB ma Japonia. W latach 2011-2013 zmniejszył się jednak w tym kraju poziom recesji gospodarczej. W pozostałych - USA, Wielkiej Brytanii i strefie euro - następuje wyraźna poprawa koniunktury gospodarczej. Potwierdza ona stanowisko MFW, który uznał, że świat w pierwszej fazie luzowania ilościowego per saldo zyskał pod względem wzrostu gospodarczego i stworzył silny bodziec dla realnej gospodarki. Wzmacnia też poglądy zwolenników tej polityki wskazujących, że w krótkim czasie pozwoliła ona uniknąć, głównie Stanom Zjednoczonym, wielkiej depresji i takiej samej recesji. Efektem poluzowania polityki pieniężnej był bowiem spadek amerykańskiego PKB 4-5\%. Gdyby luzowania ilościowego nie 
zastosowano, PKB w USA spadłby prawie o 30\%. Powstrzymanie tych negatywnych skutków wzmacnia stronę krótkookresowych korzyści luzowania ilościowego [Długotrwałe... 2013, s. 7]. Poziom PKB w analizowanych państwach jest jednak niższy niż jego wieloletnia średnia. Wstrzymuje to realizację strategii wyjścia, a zatem otwarta pozostaje kwestia ogłoszenia terminu zamknięcia skupu aktywów finansowych przez banki centralne.

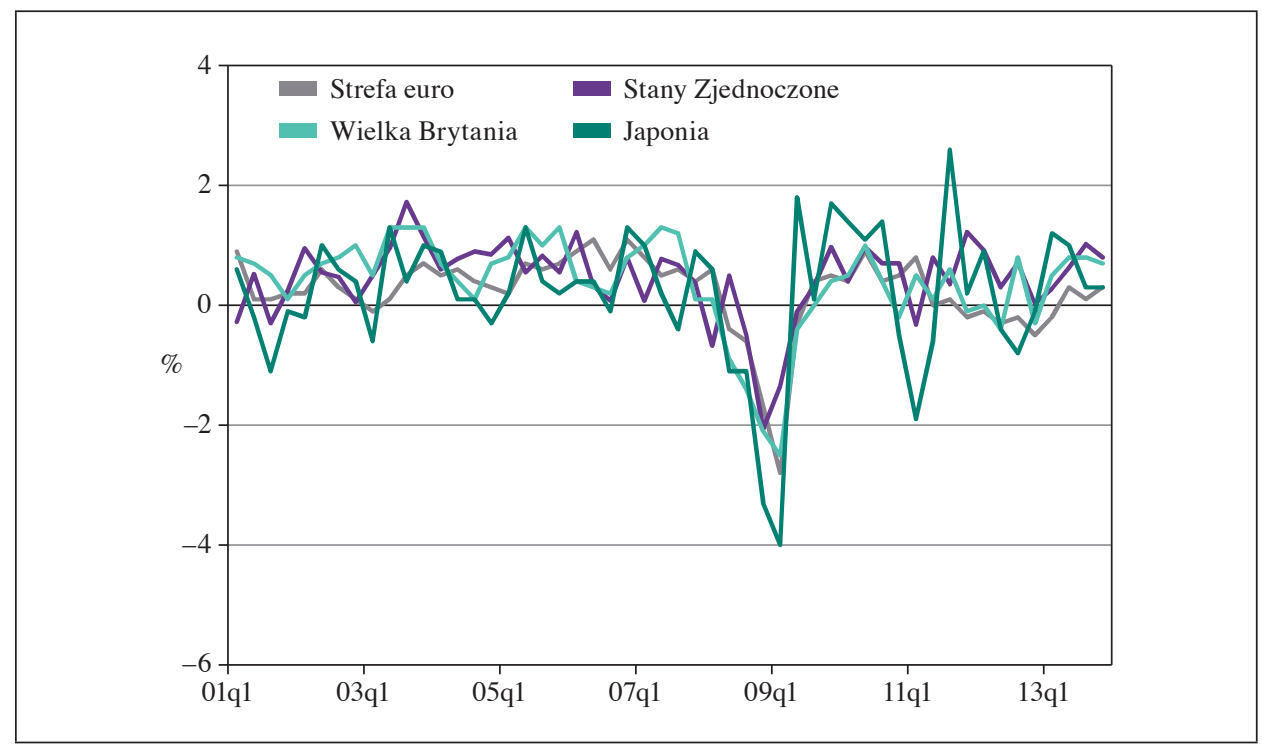

Rys. 1. Wzrost gospodarczy w wybranych gospodarkach rozwiniętych (kwartał do kwartału)

Źródło: http://www.nbp.pl/home.aspx?f=/polityka_piniezna/dokumenty/raport_o_inflacji_2014. html, listopad 2014, s. 9 (data dostępu: 2.02.2015).

Banki centralne w państwach stosujących politykę luzowania ilościowego borykają się nadal z poważnymi problemami zatrudnienia i bezrobocia. W USA, gdzie od $2011 \mathrm{r}$. zatrudnienie $\mathrm{w}$ gospodarce powoli rośnie, zbyt wysoki pozostaje poziom bezrobocia [Raport o inflacji 2014]. Banki centralne w tych okolicznościach nie mają społecznego mandatu wycofania się z polityki luzowania ilościowego.

Wejście największych banków centralnych w fazę QE3 wzmacnia dodatkowo najsilniejszy dotychczas argument exit strategy, jakim jest obawa przed inflacją. W krajach rozwiniętych pozostaje ona stale na niskim poziomie, pomimo obserwowanego jej nieznacznego wzrostu w latach 2013-2014. W Stanach Zjednoczonych inflacja bazowa jest jednak stabilna, natomiast w strefie euro obniżyła się (rys. 2). Reakcja gospodarki światowej na luzowanie ilościowe jest więc wobec argumentu inflacyjnego zaskakująca. Wydaje się bowiem nie istnieć obserwowana 
dotychczas klasyczna relacja między wzrostem podaży pieniądza i wzrostem cen. Z pewnością nie wystąpiła ona w krótkim okresie. Stąd oczekuje się napięć inflacyjnych jako konsekwencji luzowania ilościowego w długim terminie. Czy jednak one wystąpią - nikt tego nie określa.

Wskazuje się natomiast na międzynarodowe skutki rozluźnienia ilościowego jako przyczynę wyhamowania inflacji w gospodarkach wysoko rozwiniętych. To bowiem kraje wschodzące w latach 2009-2010 ponosiły jego największe konsekwencje. Pompowany w nadmiarze do gospodarki, nie tylko amerykańskiej, pieniądz w poszukiwaniu wyższych stóp rentowności inwestowanego kapitału finansowego przelewał się do krajów wschodzących, aprecjonując wartość ich walut krajowych. Koronnym przykładem jest Brazylia, która posunęła się wręcz do ograniczeń kapitałowych. Zrobiło to jednak także kilka innych krajów. Dlatego też gdy w maju 2013 r. Fed, nie biorąc pod uwagę sytuacji na rynku pracy, ogłosił koniec dodatkowego druku dolarów, spowodowało to natychmiastowe umocnienie dolara wobec euro i jena. Kraje wschodzące stanęły przed problemem gwałtownej dewaluacji ich walut. Wiadomo jednak, że Fed zmienił swoje nastawienie do polityki luzowania ilościowego, co uspokoiło nastroje na rynkach walutowych.

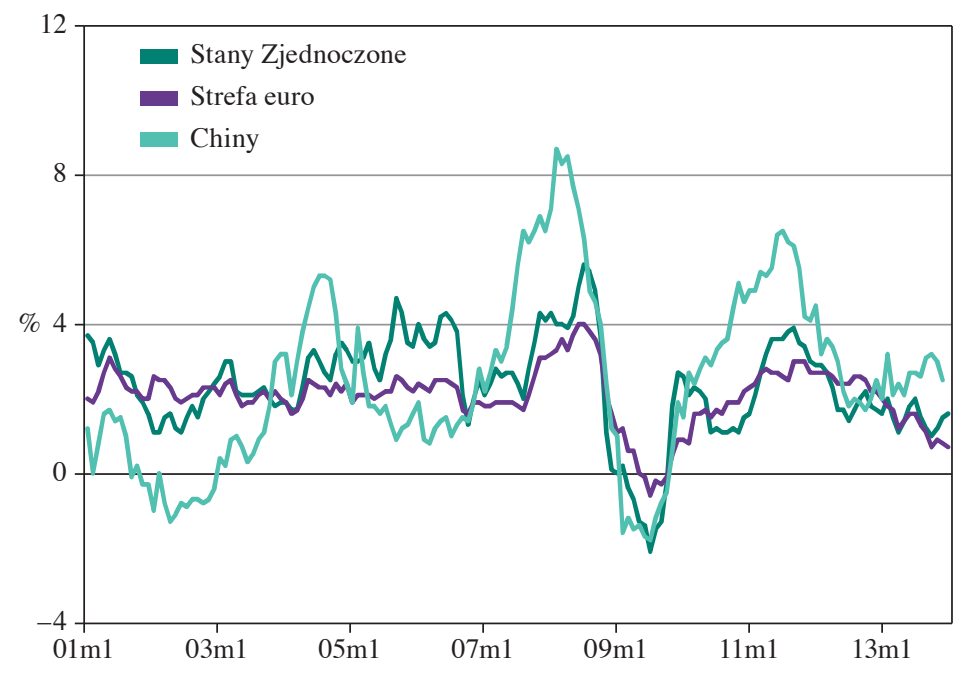

Rys. 2. Inflacja mierzona CPI (Stany Zjednoczone i Chiny) oraz HICP (strefa euro) rok do roku

Źródło: http://www.nbp.pl/home.aspx?f=/polityka_piniezna/dokumenty/raport_o_inflacji_2014. html, listopad 2014, s. 12 (data dostępu: 2.02.2015). 
Niepewność wyjścia z polityki luzowania ilościowego sprzyja jednak transakcjom spekulacyjnym w różnych obszarach rynku finansowego. Rynki finansowe reagują bowiem na każdą zapowiedź banków centralnych zmianą rentowności znajdujących się na nich aktywów. Rys. 3 przedstawia rentowność dziesięcioletnich obligacji skarbowych w wybranych krajach. Z wyjątkiem Japonii wyraźny jest jej spadek i relatywnie wysoka zmienność. Można wykazać, że amplituda wahań rentowności dziesięcioletnich obligacji skarbowych jest ściśle skorelowana z zapowiedziami banków centralnych (np. Fed i EBC) łagodzenia czy też ograniczania polityki luzowania ilościowego. W sytuacji gdy skala luzowania ilościowego się zmniejsza, rentowność tych obligacji wzrasta, i odwrotnie. Trudno zaprzeczyć, że zmiany te sprzyjają transakcjom spekulacyjnym, zwiększając ryzyko inwestycyjne i finansowe w skali lokalnej i międzynarodowej. Z pewnością nie jest to właściwy argument za kontynuowaniem polityki luzowania ilościowego. Pieniądz gotówkowy „pompowany” do systemu finansowego nie sprzyja bowiem finansowaniu sfery realnej, lecz wysokim zyskom dużych instytucji finansowych.

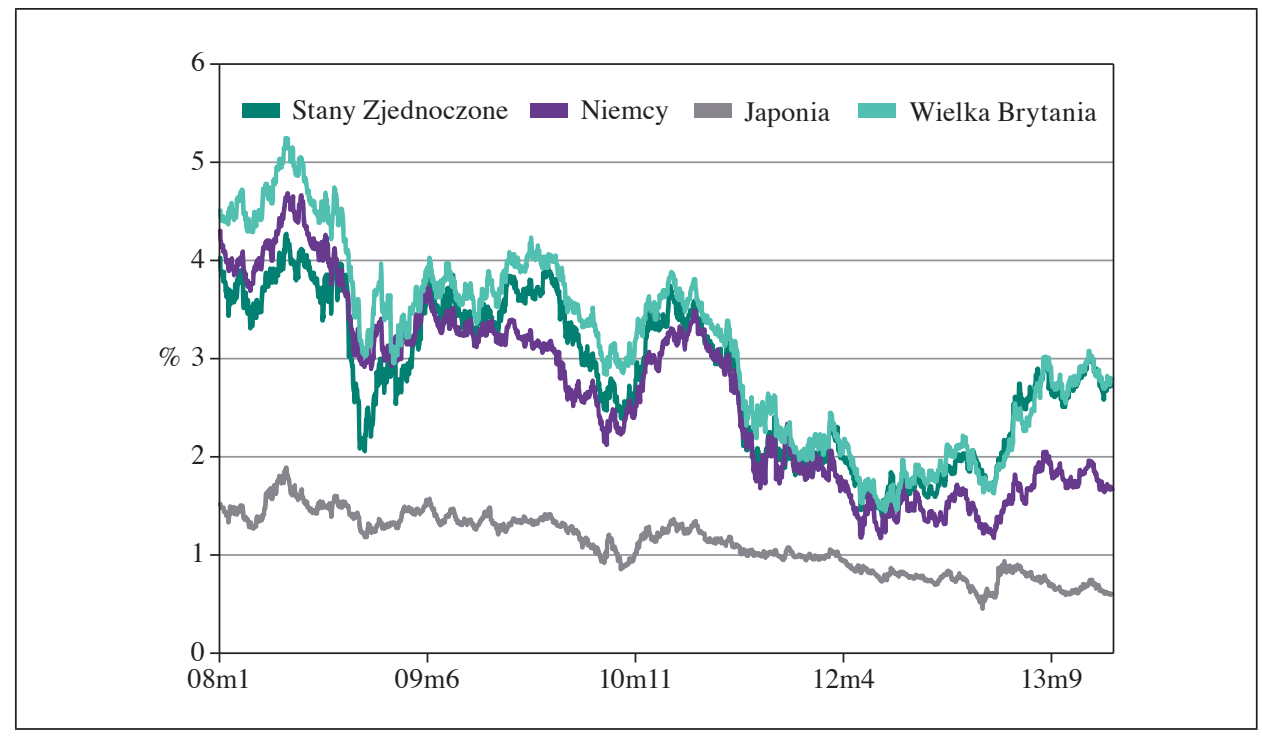

Rys. 3. Rentowności dziesięcioletnich obligacji skarbowych w Stanach Zjednoczonych, Niemczech, Wielkiej Brytanii i Japonii

Źródło: http://www.nbp.pl/home.aspx?f=/polityka_piniezna/dokumenty/raport_o_inflacji_2014. html, listopad 2014, s. 19 (data dostępu: 2.02.2015).

Utrzymujący się w państwach dotkniętych globalnym kryzysem finansowym niski poziom kredytowania podmiotów sfery realnej pokazuje także, że utrzymywanie przez banki niskiego oprocentowania pieniądza bankowego jest tylko 
częściowo uzasadnione poprawą koniunktury gospodarczej. Stopy te w największych bankach centralnych gospodarki światowej są na poziomach bliskich lub równych zeru. Banki centralne wydają się dostrzegać potrzebę wzrostu tej stopy. Jednym z ważnych, podawanych często argumentów jest przypisywanie im poprzez utrzymywanie takiej polityki wspierania niskich kosztów finansowania długu publicznego. Wiadomo jednak, że wzrost stóp procentowych skończyłby się szybko zmianą kursów walutowych. Pytanie brzmi, czy banki centralne i gospodarka są na tę okoliczność przygotowane? Z wypowiedzi prezesów banków centralnych można wnosić, że nie.

EBC w listopadzie 2013 r. obniżył stopy procentowe o 0,25 pkt proc., w tym stopę podstawowych operacji refinansujących do poziomu $0,25 \%$, pozostawiając jedynie na tym samym poziomie $0,00 \%$ stopę depozytową. Ponadto EBC ponownie zadeklarował zamiar pozostawienia stóp procentowych przez dłuższy czas na bieżącym lub niższym poziomie. Również Fed zobowiązał się, że będzie utrzymywał krótkoterminowe stopy procentowe na niskim poziomie bliskim zera $(0,00$ $0,25)$, i to w okresie dłuższym, niż gdy stopa bezrobocia obniży się poniżej $6,5 \%$.

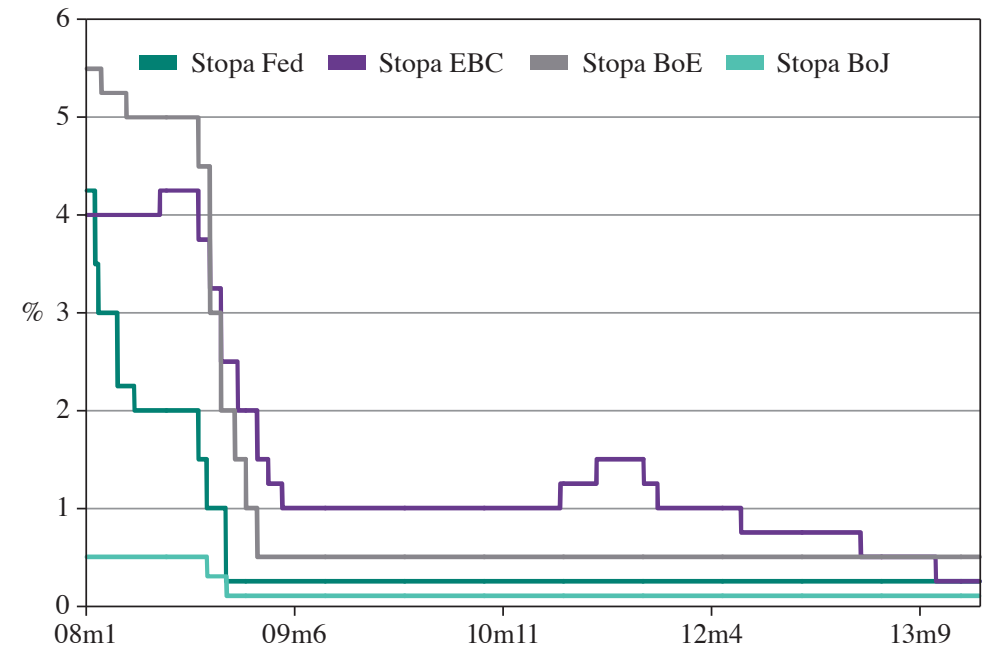

Rys. 4. Stopy procentowe głównych banków centralnych

Źródło: http://www.nbp.pl/home.aspx?f=/polityka_piniezna/dokumenty/raport_o_inflacji_2014. html, listopad 2014, s. 16 (data dostępu: 2.02.2015).

Banki centralne nie zamierzają więc rezygnować z polityki luzowania ilościowego pomimo wcześniejszych deklaracji, wysyłają natomiast do gospodarki różne sygnały. Fed z jednej strony nie podejmuje się rewolucji w prowadzeniu amery- 
kańskiej polityki pieniężnej, z drugiej strony zapowiada możliwość wygaszania programu QE już w najbliższej przyszłości.

Obniżając wartość programu luzowania ilościowego, w którym comiesięcznie skupuje aktywa finansowe, w tym obligacje skarbowe i obligacje zabezpieczone hipotekami MBS z 75 do 65 mld dolarów, Fed zapowiedział jednocześnie, że będzie co miesiąc skupował obligacje skarbowe warte 35 mld i obligacje zabezpieczone hipotekami MBS warte 30 mld. Decyzja jest potwierdzeniem strategii amerykańskiego banku centralnego, zakładającej, że Fed będzie stopniowo, małymi krokami wycofywał się z bezprecedensowego programu pobudzania wzrostu, aż sytuacja gospodarcza poprawi się.

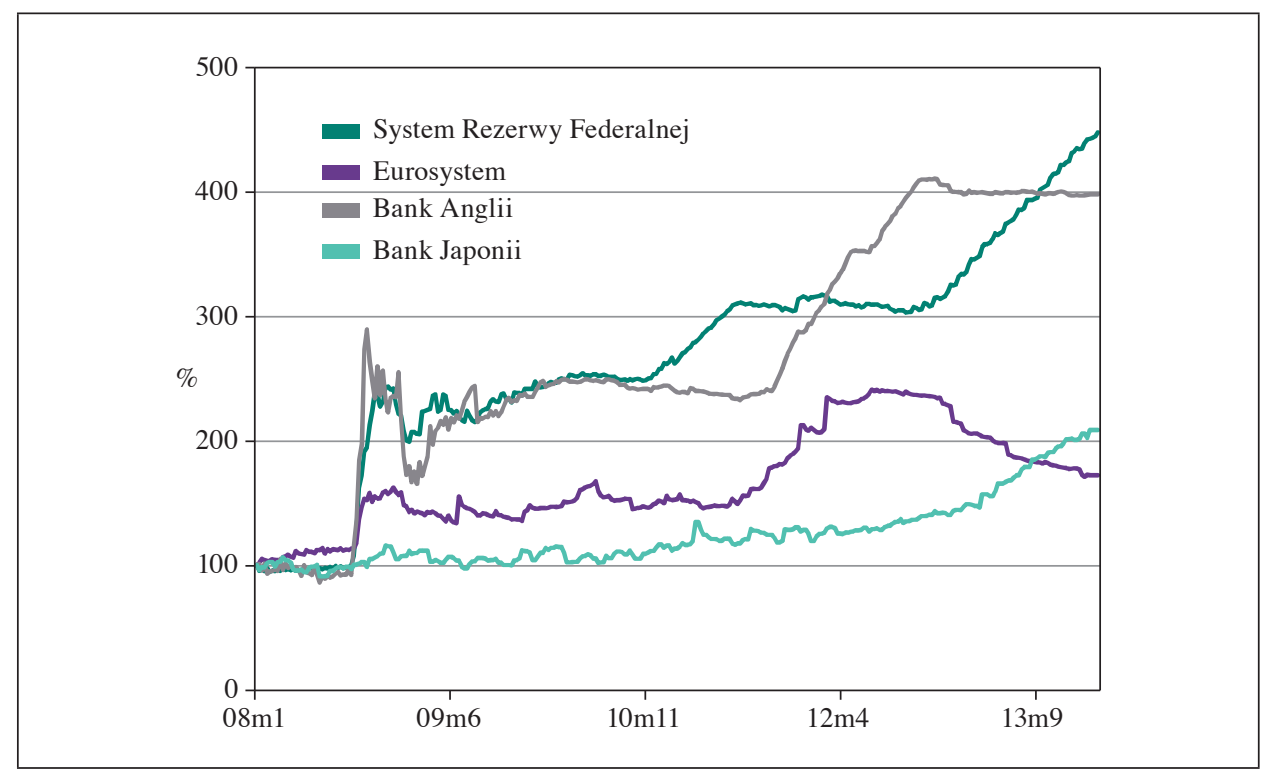

Rys. 5. Sumy bilansowe głównych banków centralnych (styczeń $2008=100$ )

Źródło: http://www.nbp.pl/home.aspx?f=/polityka_piniezna/dokumenty/raport_o_inflacji_2014. html, listopad 2014, s. 16 (data dostępu: 2.02.2015).

Podobne deklaracje można usłyszeć ze strony EBC. W styczniu 2014 r. EBC podtrzymał gotowość do wprowadzenia programu zakupu obligacji skarbowych krajów najbardziej dotkniętych kryzysem zadłużeniowym oraz możliwość uruchomienia nowego programu zasilania banków w płynność. Tymczasem coraz bardziej ryzykowne stają się bilanse banków centralnych wskutek polityki luzowania ilościowego (rys. 5). Odejście od luzowania ilościowego okazuje się znacznie trudniejsze, niż przypuszczano. Banki centralne poszukują dobrej drogi wyjścia z tej polityki. Nie wiadomo tylko, czy ona istnieje. 


\section{Podsumowanie}

Wprowadzenie przez banki centralne luzowania ilościowego jako instrumentu nadzwyczajnego polityki monetarnej okazało się w krótkim okresie skuteczne. Gospodarka światowa weszła obecnie na ścieżkę wzrostu gospodarczego. W sektorze finansowym nastąpiło wyhamowanie jego niestabilności. Konsekwencje polityki luzowania ilościowego są jednak szerokie i różnorodne. Można je, zgodnie z kolejnością ogłaszanych programów skupu papierów wartościowych, podzielić na różne fazy. Można je też identyfikować w sferze realnej i sferze finansowej. W końcu można je rozpatrywać w krótkim i długim okresie.

Ocena skutków polityki luzowania ilościowego nie zawsze jest pozytywna. Wielką niewiadomą pozostaje jej długoterminowy wpływ na inflację gospodarczą. Poważnym problemem banków centralnych jest powodowana tą polityką niestabilność kursów walutowych i cen rynkowych oraz aktywów finansowych. Banki centralne, obawiając się skutków realizacji tzw. strategii wyjścia, zastosowały politykę stopniowego wycofywania się z quantitative easing.

\section{Literatura}

Banki centralne wobec kryzysu ekonomicznego [2010], red. J. Osiński, SGH, Warszawa. Bernanke B. [2009], The Crisis and the Policy Response, Remarks at the Stamp Lecture, London School of Economics, January 13.

Borio C., Disyatat P. [2009], Unconventional Monetary Policies: An Appraisal, „BIS Working Papers", nr 292, http://dx.doi.org/10.2139/ssrn.1541243.

Długofalowe skutki polityki niskich stóp procentowych i poluzowania polityki pieniężnej [2013], BRE Bank CASE, z. 129.

Gray S., Hoggarth G. [1996], Introduction to Monetary Operations, Handbooks in Central Banking, nr 10, Centre for Central Bank Studies, Bank of England.

Issing O. [2009], Assets Prices and Monetary Policy, „Cato Journal”, nr 1.

Murray J. [2009], When the Unconvencional Becomes Conventional. Monetary Policy in Extraordinary Times, „Bank of International Settlements Reviev”, nr 61.

Pyka I. [2013], Polityka monetarna EBC wobec przemian instytucjonalnych $w$ strefie euro, „Zarządzanie i Finanse. Journal of Management and Finance”, nr 2, cz. 1.

Raport o inflacji [2014], NBP, Warszawa.

Smaghi L.B. [2009], Conventional and Unconventional Monetary Policy, Keynote Lecture at the International Center for Monetary and Banking Studies (ICMB), Geneva, 28 April 2009.

Tymoczko D. [2010], Banki centralne w zarzqdzaniu kryzysem finansowym, 111 seminarium BRE-CASE, Warszawa.

Wróbel Ł. [2012], Po trzecie, wyluzuj, „Parkiet”, nr 231. 


\section{Dilemmas of Central Banks in the Face of Quantitative Easing Policy}

The study focuses on the analysis of the character and form of quantitative easing policy, used by central banks during the global financial crisis. Its main aim is to assess the consequences of this policy, which are analysed from the point of view of both theory and practice. The study indicates their diversity, which determines the implementation of exit strategy by central banks.

Keywords: monetary expansion, non-standard monetary policy instruments, quantitative easing policy, unconventional monetary policy, exit strategies, central bank's balance sheet, creation of credit money. 